\title{
Tingkat asupan energi dan ketersediaan pangan berhubungan dengan risiko kekurangan energi kronik (KEK) pada ibu hamil
}

\author{
Intake of energy and food availability associated with the risk of chronic energy deficiency \\ in pregnant women
}

\author{
Yanuarti Petrika1 ${ }^{1}$,Hamam Hadi², Detty Siti Nurdiati ${ }^{3}$
}

\begin{abstract}
Background: Chronic energy deficiency (CED) is one of nutritional problems in pregnant women. One of the causes is inadequate energy and protein in food consumption, and low household food availability. Objectives: To know association between energy and protein intakes, food availability with CED in pregnant women in Sedayu Subdistrict, Bantul, Yogyakarta.

Methods: This was an observational study with cross sectional design. This study was conducted in Sedayu Subdistrict, Bantul, Yogyakarta from March to May 2014 and 201 pregnant women were selected as samples by using total sampling methods. Independent variable was the level of energy intake, protein, and food availability while the dependent variable was the risk of CED in pregnant women. Data were collected by direct interview with questionnaire and direct measurement of mid upper arm circumference (MUAC) with MUAC tape. Data were then analyzed by using univariable analysis (descriptive), bivariable (chi-square), and multivariable (multiple logistic regression).

Results: Bivariable test showed a significant association between level of energy intake (OR=3, 95\% Cl:1.3-6.8) and food availability (OR=2.9, 95\% Cl:1.1-7.1) with the risk of CED in pregnant women in Sedayu Subdistrict. However, no significant association between level of protein intake and the risk of CED $(O R=2.1,95 \% \mathrm{Cl}: 0.9-5.1)$. In multivariable analysis, level of energy intake had the strongest association with the risk of CED.

Conclusions: There was associaton between level of energy intake and food availability with the risk of CED in pregnant women. However, there was no association between level of protein intake and the risk of CED in pregnant women.
\end{abstract}

KEYWORDS: chronic energi deficiency, pregnant women, intake of energy intake of protein, food availability

\begin{abstract}
ABSTRAK
Latar belakang: Kekurangan energi kronis (KEK) merupakan salah satu masalah gizi yang terjadi pada ibu hamil. Salah satu penyebab KEK adalah konsumsi makan yang tidak cukup mengandung energi dan protein serta ketersediaan pangan keluarga yang kurang.

Tujuan: Untuk mengetahui hubungan antara tingkat asupan energi, tingkat asupan protein, dan ketersediaan pangan dengan kejadian KEK pada ibu hamil di Kecamatan Sedayu, Bantul, Yogyakarta. Metode: Desain penelitian ini adalah cross sectional yang dilakukan di Kecamatan Sedayu Bantul pada bulan Maret hingga Mei 2014. Populasi adalah seluruh ibu hamil di Kecamatan Sedayu yang diambil dengan metode total sampling dan didapatkan 201 orang. Variabel bebas yaitu tingkat asupan energi, protein, dan ketersediaan pangan, sedangkan variabel terikat adalah risiko KEK pada ibu hamil. Data
\end{abstract}

\footnotetext{
1 Pasca Sarjana Gizi dan Kesehatan Fakultas Kedokteran Universitas Gadjah Mada, Jl. Farmako Sekip Utara Yogyakarta, e-mail: richa.lover87@gmail.com

${ }^{2}$ Magister Gizi dan Kesehatan, Fakultas Kedokteran Universitas Gadjah Mada, Jl. Farmako, Sekip Utara, Yogyakarta 55281, e-mail: hamamhadi99@gmail.com

${ }^{2}$ Bagian Obstetri dan Ginekologi RSUP Dr. Sardjito, Jl.Kesehatan,Yogyakarta, e-mail: dnurdiaty@yahoo.com
} 
diambil dengan wawancara langsung menggunakan software kuesioner Commcare dan pengukuran lingkar lengan atas (LILA) dengan pita LILA. Data dianalisis dengan analisis univariabel (deskriptif), bivariat (chi-square), dan multivariat (regresi logistik berganda).

Hasil: Analisis bivariat menunjukkan bahwa terdapat hubungan yang signifikan antara tingkat asupan energi $(O R=3,95 \%$ Cl:1,3-6,8) dan ketersediaan pangan (OR=2,9, 95\% Cl:1,1-7,1) dengan risiko KEK pada ibu hamil. Tidak terdapat hubungan yang signifikan antara tingkat asupan protein dengan risiko KEK $(O R=2,1$, $95 \%$ Cl:0,9-5,1). Pada analisis multivariat, tingkat asupan energi memiliki hubungan paling kuat dengan risiko KEK dibandingkan dengan variabel lainnya.

Kesimpulan: Terdapat hubungan antara tingkat asupan energi dan ketersediaan pangan dengan risiko KEK pada ibu hamil. Namun tidak terdapat hubungan antara tingkat asupan protein dengan risiko KEK pada ibu hamil.

KATA KUNCI: kekurangan energi kronis, ibu hamil, asupan energi, asupan protein, ketersediaan pangan

\section{PENDAHULUAN}

Salah satu masalah gizi yang dihadapi di Indonesia adalah masalah gizi kehamilan (1). Kekurangan energi kronis (KEK) merupakan salah satu masalah gizi yang terjadi pada ibu hamil. KEK adalah keadaan kekurangan asupan energi dan protein pada wanita usia subur (WUS) yang berlangsung secara terus menerus dan mengakibatkan gangguan kesehatan (2). Permasalahan KEK ini telah dialami oleh negaranegara berkembang seperti Bangladesh, India, Indonesia, Myanmar, Nepal, Srilanka, dan Thailand. Prevalensi ibu hamil yang mengalami KEK pada tahun 2013 di Indonesia sebesar 24,2\% dan mengalami peningkatan dibandingkan prevalensi risiko KEK tahun 2007 sebesar 21,6\% (3), sementara di Daerah Istimewa Yogyakarta (DIY) berdasarkan data Profil Kesehatan Provinsi DIY tahun 2011 yaitu $14,8 \%$ meningkat dibandingkan tahun 2010 sebesar $14,41 \%$ (4).

Salah satu faktor penyebab KEK adalah konsumsi makan yang tidak cukup mengandung energi dan protein. Kehamilan menyebabkan meningkatnya metabolisme energi, sehingga kebutuhan energi dan zat gizi lainnya meningkat. Selama kehamilan, diperlukan tambahan energi ekstra sebesar 340-450 Kalori setiap hari pada trimester II dan III $(5,6)$. Kekurangan asupan energi selama kehamilan juga akan mempengaruhi kebutuhan protein. Jika ibu kekurangan zat energi maka fungsi protein untuk membentuk glukosa akan didahulukan. Pemecahan protein tubuh ini pada akhirnya akan menyebabkan melemahnya otototot dan jika hal ini terjadi secara terus menerus, akan terjadi deplesi masa otot karena salah satu fungsi dari protein adalah untuk pertumbuhan dan pemeliharaan sel-sel (7).

Salah satu dampak yang dapat dialami ibu hamil jika asupan zat gizi kurang yaitu akan mengalami KEK yang dilihat berdasarkan pengukuran lingkar lengan atas (LILA). Pengukuran LILA merupakan salah satu pengukuran antropometri untuk mengetahui ibu hamil tersebut menderita KEK atau tidak. Hasil LILA $<23,5 \mathrm{~cm}$ menandakan telah terjadi penurunan massa otot akibat kurangnya protein di dalam tubuh dan menandakan bahwa telah terjadi kekurangan energi secara kronis $(8,9)$.

Faktor-faktor lain yang berhubungan dengan KEK pada ibu hamil yaitu tidak tersedianya pangan secara musiman atau secara kronis di tingkat rumah tangga (10). Ketersediaan pangan sangat bergantung dari daya beli keluarga. Jika daya beli keluarga menurun, maka ketersedian pangan juga akan menurun, begitu juga sebaliknya. Jika ketersediaan pangan di rumah tangga menurun, maka konsumsi makan dan asupan zat gizi per anggota keluarga berkurang sehingga menyebabkan masalah gizi (11).

Kabupaten Bantul merupakan salah satu kabupaten yang ada di Provinsi DIY. Konsumsi pangan masyarakat Bantul masih belum beragam karena masih ada dominasi kelompok pangan tertentu yaitu padi, umbi-umbian, kacang-kacangan, sayuran, dan buah. Hal tersebut dapat disebabkan 
oleh akses dan keterjangkauan masyarakat terhadap pangan masih rendah $(12,13)$. Berdasarkan data tersebut, dapat dimungkinkan tingkat konsumsi pangan masyarakat tersebut tidak seimbang dan tidak sesuai dengan kebutuhan yang dianjurkan sehingga kejadian kurang gizi khususnya KEK pada ibu hamil masih terjadi. Kondisi ini secara nyata terlihat dari prevalensi ibu hamil KEK di Kabupaten Bantul sebesar 13,8\% dan Sedayu (I dan II) 11,4\% (14). Walaupun prevalensi di Kabupaten Bantul dan Sedayu lebih rendah dibandingkan Indonesia dan Yogyakarta, namun prevalensi ini masih menjadi permasalahan gizi dan diharapkan tidak ada lagi ibu hamil yang menderita KEK.

Berdasarkan latar belakang tersebut, penulis bermaksud melakukan penelitian mengenai hubungan antara tingkat asupan energi dan protein serta ketersediaan pangan keluarga dengan risiko KEK pada ibu hamil di Kecamatan Sedayu Kabupaten Bantul.

\section{BAHAN DAN METODE}

Penelitian ini menggunakan desain cross sectional yang dilakukan di Kecamatan Sedayu Kabupaten Bantul pada periode bulan Maret hingga Mei 2014. Penelitian ini merupakan bagian dari penelitian yang berjudul "Status Gizi Ibu Hamil dan Baduta di Kecamatan Sedayu Kabupaten Bantul D.I Yogyakarta" yang dilaksanakan oleh Alma Ata Center For Healthy Life and Food (ACHEAF) Yogyakarta. Subjek penelitian adalah seluruh ibu hamil di Kecamatan Sedayu Kabupaten Bantul yang telah sesuai dengan kriteria inklusi dan eksklusi. Kriteria inklusi yaitu berdomisili di Kecamatan Sedayu Kabupaten Bantul, setuju untuk berpartisipasi, menandatangani formulir persetujuan, dan kehamilan tunggal (janin tidak kembar). Kriteria eksklusi yaitu ibu hamil yang dalam perawatan atau pernah menderita penyakit selama 3 bulan ke belakang yang mengganggu asupan makanan, mengalami edema bagian atas terutama lengan tangan, tidak mempunyai tangan (cacat) dan menderita penyakit penyerta yang berat seperti gangguan kesadaran/koma. Teknik pengambilan sampel pada penelitian ini menggunakan teknik total sampling dengan mengambil sampel dari seluruh ibu hamil yang berdomisili di Kecamatan Sedayu, Kabupaten Bantul. Jumlah sampel dalam penelitian ini adalah 201 ibu hamil.

Variabel terikat pada penelitian ini adalah risiko KEK pada ibu. Variabel bebasnya yaitu tingkat asupan energi, protein, dan ketersediaan pangan. Variabel perancu yaitu usia ibu, usia kehamilan, tingkat pendidikan ibu, tingkat pengetahuan ibu, pekerjaan ibu, paritas, tingkat pendapatan keluarga, dan tingkat pengeluaran pangan. Data diambil dengan melakukan wawancara langsung kepada responden dengan menggunakan kuesioner dan data yang diambil berupa konsumsi makan dengan semi-quantitative food frequency questionnaire (SQ$F F Q$ ), ketersediaan pangan, usia ibu, usia kehamilan, tingkat pendidikan ibu, tingkat pengetahuan ibu, pekerjaan ibu, paritas, tingkat pendapatan keluarga, dan tingkat pengeluaran pangan. Selain itu, melakukan pengukuran antropometri langsung berupa pengukuran LILA dengan menggunakan pita LILA.

Pada penelitian ini, uji validitas menggunakan analisis corrected item-total correlation. Pada uji validitas instrumen pengetahuan gizi, dari 20 item terdapat 12 item yang dinyatakan valid. Uji reliabilitas pada penelitian ini menggunakan metode cronbach's alpha. Pada penelitian ini, uji reliabilitas kuesioner pengetahuan gizi, diperoleh nilai cronbach's alpha sebesar 0,816 sehingga dapat dikatakan bahwa semua item pada kuesioner pengetahuan gizi tersebut reliabel dan reliabilitasnya bisa dikatakan tinggi/baik. Penelitian ini telah mendapatkan persetujuan dari Komisi Etik Penelitian Kedokteran dan Kesehatan Fakultas Kedokteran Universitas Gadjah Mada Yogyakarta No Ref: KE/FK/382/EC tahun 2014.

\section{HASIL}

Data gambaran distribusi frekuensi karakteristik ibu hamil yang dilihat dari status gizi, tingkat asupan energi, tingkat asupan protein, dan ketersediaan pangan ibu hamil pada Tabel 1 terlihat bahwa proporsi ibu hamil yang risiko KEK lebih sedikit yaitu sebesar $17,9 \%$ dibandingkan dengan ibu 
Tabel 1. Distribusi frekuensi karakteristik ibu hamil

\begin{tabular}{lcc}
\hline \multicolumn{1}{c}{ Variabel } & $\mathbf{n}$ & $\mathbf{\%}$ \\
\hline Status gizi ibu hamil & & \\
$\quad$ Risiko KEK & 36 & 17,9 \\
$\quad$ Tidak berisiko KEK & 165 & 82,1 \\
Tingkat asupan energi & & \\
$\quad$ Rendah & 59 & 29,4 \\
$\quad$ Cukup & 142 & 70,7 \\
Tingkat asupan protein & & \\
$\quad$ Rendah & 118 & 58,7 \\
$\quad$ Cukup & 83 & 41,3 \\
Ketersediaan pangan & & \\
$\quad$ Rawan kelaparan tingkat berat & 6 & 2,9 \\
$\quad$ Rawan kelaparan tingkat sedang & 7 & 3,5 \\
$\quad$ Rawan tanpa kelaparan & 20 & 9,9 \\
$\quad$ Terjamin & 168 & 83,4 \\
\hline
\end{tabular}

hamil yang tidak berisiko KEK yaitu sebesar $82,1 \%$, namun prevalensi ini cukup tinggi jika dibandingkan dengan prevalensi KEK di DIY dan Bantul. Proporsi tingkat asupan energi lebih banyak yang cukup yaitu sebesar $70,7 \%$, namun, tingkat asupan protein ibu hamil lebih banyak rendah yaitu sebesar $58,7 \%$. Ketersediaan pangan keluarga ibu hamil lebih banyak terjamin dengan proporsi $83,6 \%$ dan hanya sebagian kecil dengan rawan tanpa kelaparan $(9,9 \%)$, rawan kelaparan tingkat sedang $(3,5 \%)$, dan rawan kelaparan tingkat berat $(2,9 \%)$.

Berdasarkan hasil analisis bivariat pada Tabel 2, dapat diketahui bahwa ibu hamil yang berpendidikan rendah lebih banyak pada kelompok risiko KEK $(33,3 \%)$ dibandingkan dengan tidak

Tabel 2. Hubungan antara tingkat pendidikan ibu, pekerjaan ibu, tingkat pendapatan, tingkat pengeluaran pangan, usia ibu, paritas, umur kehamilan, dan tingkat pengetahuan gizi ibu dengan status gizi pada ibu hamil

\begin{tabular}{|c|c|c|c|c|c|c|}
\hline \multirow{3}{*}{ Karakteristik } & \multicolumn{4}{|c|}{ Status gizi ibu hamil } & \multirow{3}{*}{ OR } & \multirow{3}{*}{$\begin{array}{c}p \\
(95 \% \mathrm{Cl})\end{array}$} \\
\hline & \multicolumn{2}{|c|}{ Risiko KEK } & \multicolumn{2}{|c|}{ Tidak berisiko KEK } & & \\
\hline & $n$ & $\%$ & $\mathbf{n}$ & $\%$ & & \\
\hline \multicolumn{7}{|l|}{ Tingkat pendidikan ibu $^{\dagger}$} \\
\hline Rendah & 12 & 33,3 & 37 & 22,4 & 1,7 & 0,2 \\
\hline Tinggi & 24 & 66,7 & 128 & 77,6 & 1 & $(0,7-4,0)$ \\
\hline \multicolumn{7}{|l|}{ Pekerjaan ibu ${ }^{\dagger}$} \\
\hline Tidak bekerja & 22 & 61,1 & 87 & 52,7 & 1,4 & 0,4 \\
\hline Bekerja & 14 & 38,9 & 78 & 47,3 & 1 & $(0,6-3,2)$ \\
\hline $\begin{array}{l}\text { Persentase pengeluaran pangan dibandingkan } \\
\text { dengan total pengeluaran rumah tangga perbulan (\%) } \\
(\text { mean } \pm S D)^{\dagger+}\end{array}$ & \multicolumn{2}{|c|}{$52,1 \pm 15,0$} & \multicolumn{2}{|c|}{$53,2 \pm 17,4$} & - & $(-6,8-4,5)$ \\
\hline \multicolumn{7}{|l|}{ Tingkat pendapatan per kapita ${ }^{\dagger}$} \\
\hline Rendah & 22 & 61,1 & 82 & 49,7 & 1,6 & 0,2 \\
\hline Tinggi & 14 & 38,9 & 83 & 50,3 & 1 & $(0,7-3,6)$ \\
\hline \multicolumn{7}{|l|}{ Tingkat pengeluaran pangan per kapita ${ }^{\dagger}$} \\
\hline Rendah & 20 & 55,6 & 81 & 49,1 & 1,3 & 0,5 \\
\hline Tinggi & 16 & 44,4 & 84 & 50,9 & 1 & $(0,6-2,9)$ \\
\hline \multicolumn{7}{|l|}{ Usia ibut } \\
\hline$<20$ tahun dan $>35$ tahun & 5 & 13,9 & 31 & 18,8 & 0,7 & 0,5 \\
\hline 20-35 tahun & 31 & 86,1 & 134 & 81,2 & & $(0,2-2,0)$ \\
\hline \multicolumn{7}{|l|}{ Paritas ${ }^{\dagger}$} \\
\hline Punya anak & 21 & 58,3 & 116 & 70,3 & 0,6 & 0,2 \\
\hline Tidak punya anak & 15 & 41,7 & 49 & 29,7 & $1^{\circ}$ & $(0,3-1,3)$ \\
\hline \multicolumn{7}{|l|}{ Umur kehamilan ${ }^{\dagger}$} \\
\hline Trimester 1 dan 2 & 15 & 41,7 & 46 & 27,9 & 1,8 & 0,1 \\
\hline Trimester 3 & 21 & 58,3 & 119 & 72,1 & 1 & $(0,8-4,1)$ \\
\hline \multicolumn{7}{|l|}{ Tingkat pengetahuan ibu ${ }^{\dagger}$} \\
\hline Kurang & 26 & 72,2 & 121 & 73,3 & 0,9 & 0,9 \\
\hline Cukup & 10 & 27,8 & 44 & 26,7 & 1 & $(0,4-2,4)$ \\
\hline
\end{tabular}

* Signifikan $(p<0,05)$

† Analisis chi-square

†† Analisis t-test independent 
berisiko KEK (22,4\%). Jika dilihat dari proporsi rata-rata, persentase pengeluaran pangan pada kelompok risiko KEK yaitu $(52,1 \% \pm 15,0)$ artinya $50 \%$ lebih pengeluarannya dihabiskan untuk pangan dibandingkan dengan nonpangan. Proporsi tingkat pendapatan per kapita keluarga yang rendah lebih banyak terjadi pada kelompok risiko KEK $(61,1 \%)$, begitu juga dengan tingkat pengeluaran pangan per kapita keluarga yang rendah lebih banyak dialami pada kelompok risiko KEK (55,6\%) dibandingkan dengan yang tidak berisiko KEK $(49,1 \%)$. Dengan demikian, dapat dikatakan bahwa ibu hamil risiko KEK tingkat sosioekonominya cenderung lebih rendah. Hasil analisis pada Tabel 2 juga menunjukkan bahwa tidak terdapat hubungan yang signifikan antara tingkat pendidikan ibu, pekerjaan ibu, tingkat pendapatan, tingkat pengeluaran pangan, usia ibu, paritas, umur kehamilan, dan tingkat pengetahuan gizi ibu dengan risiko KEK pada ibu hamil $(p>0,05)$.

Tabel 3 menjelaskan bahwa ibu hamil dengan tingkat asupan energi rendah cenderung banyak terjadi pada kelompok rawan pangan $(39,4 \%)$. Hal yang sama ditunjukkan pada ibu dengan tingkat asupan protein rendah lebih banyak terjadi pada kelompok rawan pangan $(72,7 \%)$. Dengan demikian, tingkat asupan energi dan protein yang rendah pada ibu hamil lebih banyak berasal dari keluarga yang rawan pangan. Keluarga ibu hamil di Kecamatan Sedayu rata-rata yang memiliki persentase pengeluaran pangan tinggi lebih banyak terjadi pada kelompok rawan pangan yaitu sebesar $55,1 \%$ dibandingkan dengan kelompok pangan terjamin yaitu sebesar $51,7 \%$. Rata-rata persentase pengeluaran pangan pada kelompok rawan pangan ini lebih dari $50 \%$ artinya lebih dari $50 \%$ uangnya dikeluarkan untuk pangan dibandingkan dengan nonpangan dan hal ini menandakan keluarga tersebut kesejahteraannya kurang. Dengan demikian dapat dikatakan keluarga yang kurang sejahtera lebih banyak mengalami rawan pangan.

Hasil analisis pada Tabel 4, diperoleh bahwa ibu hamil dengan tingkat asupan energi rendah lebih banyak terjadi pada kelompok risiko KEK $(50,0 \%)$

Tabel 3. Hubungan antara tingkat asupan energi, protein, dan sosioekonomi dengan ketersediaan pangan keluarga ibu hamil

\begin{tabular}{|c|c|c|c|c|c|c|}
\hline \multirow{3}{*}{ Variabel } & \multicolumn{4}{|c|}{ Ketersediaan pangan } & \multirow{3}{*}{ OR } & \multirow{3}{*}{$\begin{array}{c}p \\
(95 \% \mathrm{Cl})\end{array}$} \\
\hline & \multicolumn{2}{|c|}{ Rawan pangan } & \multicolumn{2}{|c|}{ Terjamin } & & \\
\hline & $\mathbf{n}$ & $\%$ & $\mathbf{n}$ & $\%$ & & \\
\hline \multicolumn{7}{|l|}{ Tingkat asupan energi } \\
\hline Rendah & 13 & 39,4 & 46 & 27,4 & 1,7 & 0,2 \\
\hline Cukup & 20 & 60,6 & 122 & 72,6 & 1 & $(0,7-3,9)$ \\
\hline \multicolumn{7}{|l|}{ Tingkat asupan protein } \\
\hline Rendah & 24 & 72,7 & 94 & 55,9 & 2,1 & 0,07 \\
\hline Cukup & 9 & 27,3 & 74 & 44,1 & 1 & $(0,9-5,4)$ \\
\hline \multicolumn{7}{|l|}{ Persentase pengeluaran pangan dibandingkan } \\
\hline dengan total pengeluaran $(\text { mean } \pm S D)^{\dagger \dagger}$ & \multicolumn{2}{|c|}{$55,1 \pm 17,2$} & \multicolumn{2}{|c|}{$51,7 \pm 15,1$} & - & $(-9,2-2,4)$ \\
\hline \multicolumn{7}{|l|}{ Tingkat pendapatan per kapita ${ }^{\dagger}$} \\
\hline Rendah & 25 & 75,8 & 79 & 47,0 & 3,5 & 0,003 \\
\hline Tinggi & 8 & 24,2 & 89 & 52,9 & 1 & $\left(1,4-9,5^{\star}\right)$ \\
\hline \multicolumn{7}{|l|}{ Tingkat pengeluaran pangan per kapita $^{\dagger}$} \\
\hline Rendah & 19 & 57,6 & 82 & 48,8 & 1,4 & 0,4 \\
\hline Tinggi & 14 & 42,4 & 86 & 51,2 & 1 & $(0,6-3,3)$ \\
\hline \multicolumn{7}{|l|}{ Tingkat pendidikan ibu ${ }^{\dagger}$} \\
\hline Rendah & 24 & 72,7 & 25 & 14,9 & 15,3 & 0,00 \\
\hline Tinggi & 9 & 27,3 & 143 & 85,1 & 1 & $\left(5,9-41,1^{*}\right)$ \\
\hline \multicolumn{7}{|l|}{ Pekerjaan ibu ${ }^{\dagger}$} \\
\hline Tidak bekerja & 23 & 69,7 & 86 & 51,2 & 2,2 & 0,2 \\
\hline Bekerja & 10 & 30,3 & 82 & 48,8 & 1 & $(0,7-3,9)$ \\
\hline
\end{tabular}

\footnotetext{
* Signifikan (Tidak meliputi angka 1)

$\dagger$ Analisis menggunakan chi-square

†† Analisis menggunakan $t$-test independent
} 
Tabel 4. Hubungan antara tingkat asupan energi, tingkat asupan protein, dan ketersediaan pangan dengan status gizi ibu hamil

\begin{tabular}{|c|c|c|c|c|c|c|}
\hline \multirow{3}{*}{ Variabel } & \multicolumn{4}{|c|}{ Status gizi ibu hamil } & \multirow{3}{*}{ OR } & \multirow{3}{*}{$\mathbf{p}$} \\
\hline & \multicolumn{2}{|c|}{ Risiko KEK } & \multicolumn{2}{|c|}{ Tidak berisiko KEK } & & \\
\hline & $\mathbf{n}$ & $\%$ & $n$ & $\%$ & & \\
\hline \multicolumn{7}{|l|}{ Tingkat asupan energi† } \\
\hline Rendah & 18 & 50,0 & 41 & 24,9 & 3,0 & $0,003^{*}$ \\
\hline Cukup & 18 & 50,0 & 124 & 75,2 & 1 & \\
\hline \multicolumn{7}{|l|}{ Tingkat asupan protein $†$} \\
\hline Rendah & 26 & 72,2 & 92 & 55,8 & 2,1 & 0,07 \\
\hline Cukup & 10 & 27,8 & 73 & 44,2 & 1 & \\
\hline \multicolumn{7}{|l|}{ Ketersediaan pangan† } \\
\hline Rawan pangan & 11 & 30,6 & 22 & 13,3 & 2,9 & $0,01^{*}$ \\
\hline Terjamin & 25 & 69,4 & 143 & 86,7 & 1 & \\
\hline Asupan energi (Kalori) [median (Q1;Q3)]††† & \multicolumn{2}{|c|}{1580,6} & \multicolumn{2}{|c|}{2087,8} & - & $0,00^{*}$ \\
\hline Asupan protein $(\mathrm{g})$ [median $(\mathrm{Q} 1 ; \mathrm{Q} 3) \mathrm{\dagger \dagger \dagger}$ & \multicolumn{2}{|c|}{53,4} & \multicolumn{2}{|c|}{72,2} & - & $0,00^{*}$ \\
\hline
\end{tabular}

* $\quad$ Signifikan $(p<0,05)$

$\dagger$ Analisis menggunakan chi-square

†††Analisis menggunakan Mann-Whitney

dibandingkan dengan tidak berisiko KEK $(24,9 \%)$. Hasil uji statistik diperoleh nilai $\mathrm{p}=0,003$ (95\% Cl:1,3$6,8)$ maka dapat disimpulkan ada hubungan yang signifikan antara tingkat asupan energi dengan KEK pada ibu hamil $(p<0,05)$. Selain itu, dari hasil analisis diperoleh pula nilai $\mathrm{OR}=3$ artinya ibu dengan tingkat asupan energi rendah memiliki risiko 3 kali lebih besar untuk mengalami KEK dibandingkan dengan ibu yang tingkat asupan energi cukup.

Ibu hamil dengan tingkat asupan protein rendah proporsinya lebih banyak terjadi pada kelompok risiko KEK $(72,2 \%)$ dibandingkan dengan kelompok tidak berisiko KEK $(55,8 \%)$. Dilihat dari hasil uji statistik diperoleh nilai $p=0,07$ (95\% Cl:0,9$5,1)$, sehingga dapat diketahui bahwa tidak ada hubungan yang signifikan antara tingkat asupan protein dengan KEK pada ibu hamil $(p>0,05)$.

Ibu hamil dengan keluarga yang rawan pangan lebih banyak mengalami risiko KEK $(30,6 \%)$ dibandingkan dengan tidak berisiko KEK $(13,3 \%)$. Berdasarkan uji statistik didapatkan bahwa $\mathrm{p}=0,011$ $(95 \% \mathrm{Cl}: 1,1-7,1)$ artinya ada hubungan yang signifikan antara ketersediaan pangan dengan KEK pada ibu hamil. Apabila dilihat dari risikonya dapat diketahui bahwa ibu hamil dengan keluarga rawan pangan memiliki risiko 2,9 kali lebih besar untuk terkena KEK dibandingkan dengan keluarga yang pangannya terjamin. Tabel $\mathbf{4}$ juga menunjukkan bahwa terdapat perbedaan asupan energi $(p=0,00)$, dengan kecenderungan median asupan energi dan protein pada kelompok risiko KEK lebih sedikit dibandingkan kelompok tidak berisiko KEK dengan perbedaan asupan energi sebesar 507,2 Kalori dan asupan protein sebesar 18,8 gram.

Pada Gambar 1, kategori asupan energi ibu hamil berdasarkan kuartil dapat terlihat bahwa risiko KEK cenderung akan semakin meningkat jika asupan energi ibu hamil $\leq 1.926,5$ Kalori (kuartil 1 dan 2). Terjadi sedikit peningkatan proporsi risiko KEK pada ibu hamil dengan asupan energi $>1.926,5$ Kalori (kuartil 3, 4, dan 5), namun proporsi ini jauh lebih rendah dibandingkan dengan proporsi asupan energi pada kuartil 1 dan 2. Sementara pada Gambar 2, proporsi risiko KEK akan semakin menurun jika asupan protein ibu hamil $>60,7$ gram (kuartil 3, 4, dan 5). Secara keseluruhan, semakin tinggi asupan protein ibu hamil, maka proporsi risiko KEK cenderung menurun dan proporsi risiko tidak KEK cenderung meningkat.

Pada Tabel 5 dapat dilihat bahwa ada hubungan yang signifikan secara statistik antara tingkat asupan energi $(95 \% \mathrm{Cl}: 1,3-6,1)$ dan ketersediaan pangan $(95 \% \mathrm{Cl}: 1,1-6,2)$ dengan risiko KEK $(p<0,05)$. Jika dilihat dari $\mathrm{R}^{2}$ didapatkan nilai $6 \%$ artinya faktor tingkat asupan energi dan ketersediaan pangan dapat memprediksi risiko KEK 


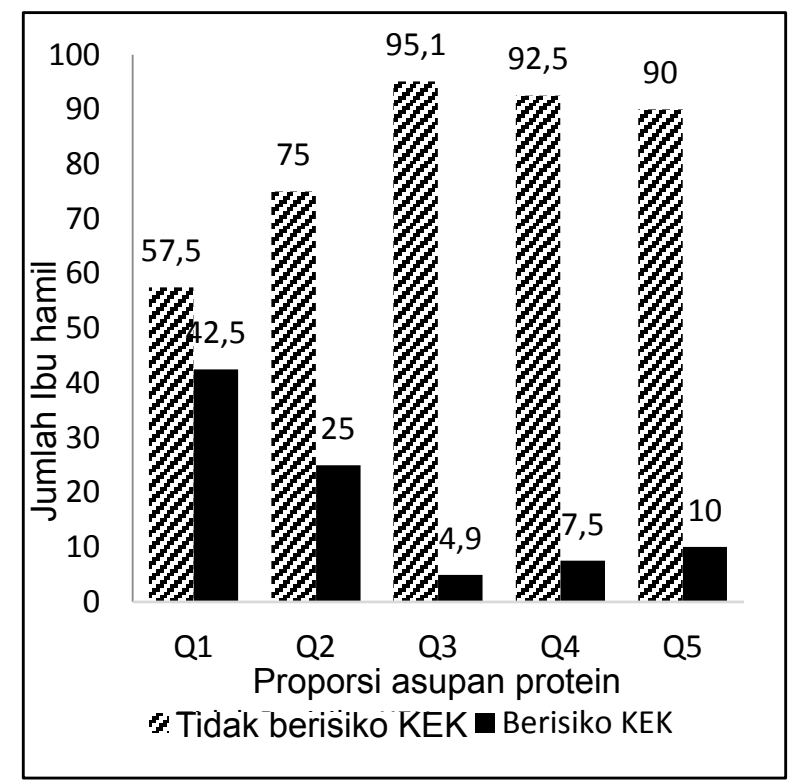

Keterangan

Kuartil 1 (Q1) : $<1.576,7$ Kalori

Kuartil 2 (Q2) : $\geq 1.576,7$ Kalori - <1.926,5 Kalori Kuartil 3 (Q3) : $\geq 1.926,5$ Kalori - $<2.143,8$ Kalori Kuartil 4 (Q4) : $\geq 2.143,8$ Kalori - <2477,2 Kalori Kuartil 5 (Q5) : $\geq 2.477,2$ Kalori

\section{Gambar 1. Proporsi asupan energi pada kelompok tidak berisiko KEK dan berisiko KEK}

Tabel 5. Analisis regresi logistik hubungan tingkat asupan energi dan ketersediaan pangan dengan risiko KEK pada ibu hamil

\begin{tabular}{crc}
\hline Variabel & OR & p (95\% CI) \\
\hline Tingkat asupan energi & & \\
$\quad$ Rendah $(<70 \% A K G)$ & 2,8 & $0,006(1,3-6,1)^{*}$ \\
$\quad$ Cukup $(\geq 70 \% A K G)$ & 1 & \\
Ketersediaan pangan & & \\
$\quad$ Rawan pangan & 2,6 & $0,03(1,1-6,2)^{\star}$ \\
$\quad$ Terjamin & 1 & \\
\hline
\end{tabular}

* Signifikan $(p<0,05)$

pada ibu hamil sebesar $6 \%$, sisanya disebabkan/ diprediksi oleh faktor lain.

Dengan demikian dapat diketahui bahwa OR dari tingkat asupan energi adalah 2,8, artinya ibu dengan tingkat asupan energi rendah memiliki risiko 2,8 kali lebih besar untuk terkena KEK dibandingkan ibu dengan tingkat asupan energi cukup. Odds ratio dari ketersediaan pangan adalah 2,6 artinya ibu dengan keluarga rawan pangan memiliki risiko 2,6 kali lebih besar untuk terkena KEK dibandingkan ibu dengan ketersediaan pangan terjamin. Dari

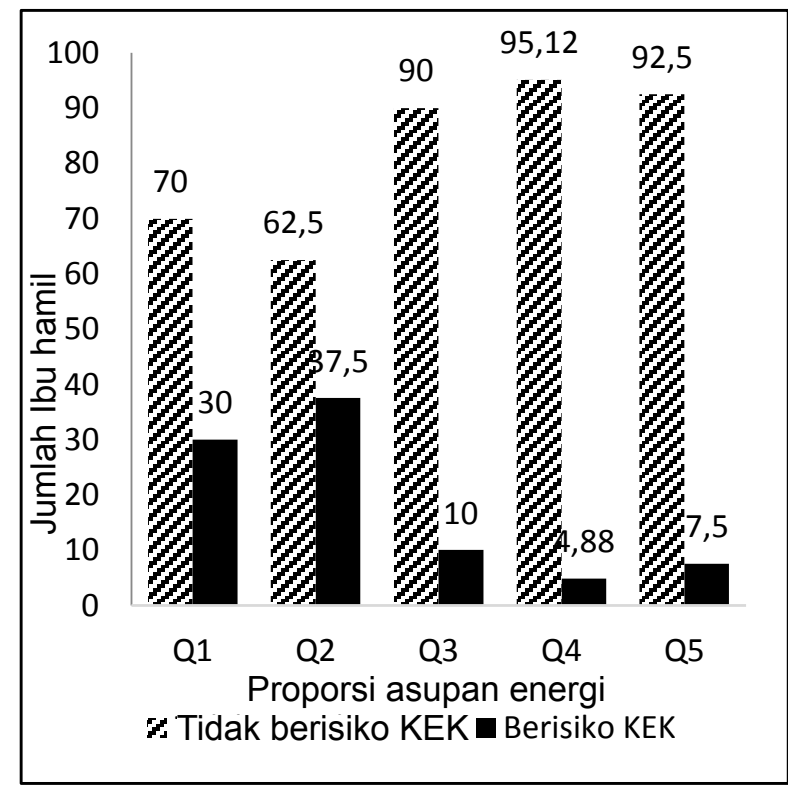

Keterangan

Kuartil 1 (Q1) : $<50,1$ gram

Kuartil 2 (Q2) : $\geq 50,1$ gram - $<60,7$ gram

Kuartil 3 (Q3) : $\geq 60,7$ gram $-<74,1$ gram

Kuartil 4 (Q4) : $\geq 74,1$ gram - $<87,9$ gram

Kuartil $5(\mathrm{Q} 5): \geq 87,9$ gram

\section{Gambar 2. Proporsi asupan protein pada kelompok} tidak berisiko KEK dan berisiko KEK

beberapa variabel bebas pada penelitian ini, tingkat asupan energi memiliki hubungan yang paling kuat dengan kejadian KEK pada ibu hamil.

\section{BAHASAN}

\section{Hubungan antara tingkat asupan energi dengan kejadian KEK pada ibu hamil}

Ibu hamil membutuhkan asupan energi yang tinggi karena adanya peningkatan metabolisme basal. Jika asupan energi tidak adekuat, maka tubuh akan menggunakan cadangan lemak. Bila cadangan lemak digunakan terus menerus dan habis, maka akan terjadi perubahan biokimia dengan cara menggunakan protein yang ada di hati dan otot untuk diubah menjadi energi. Hal ini akan menyebabkan terjadinya deplesi massa otot yang ditandai dengan hasil LILA $<23,5$ $\mathrm{cm}$, sehingga jika asupan energi rendah secara terus menerus maka KEK dapat terjadi $(15,9)$. Hal ini sejalan dengan penelitian dan sudah dibuktikan secara statistik yaitu ada hubungan yang signifikan antara tingkat asupan energi dengan risiko KEK pada 
ibu hamil (Tabel 4). Beberapa penelitian di Sidoarjo dan Sumedang menunjukkan hasil yang serupa yaitu ada hubungan yang signifikan antara tingkat asupan energi dengan risiko KEK pada ibu hamil $(16,17)$. Penelitian lain juga menyebutkan bahwa terdapat korelasi positif antara asupan energi dengan LILA, sehingga semakin meningkatnya asupan energi maka LILA juga akan semakin meningkat (18). Selain itu, pemberian suplementasi pada ibu hamil yang mengalami KEK, peningkatan berat badannya lebih signifikan dibandingkan ibu hamil yang status gizinya normal (19).

Hubungan antara tingkat asupan energi dengan risiko KEK memiliki hubungan yang kuat yang dibuktikan dengan analisis multivariat yang menunjukkan bahwa ibu hamil dengan tingkat asupan energi yang rendah memiliki peluang 2,8 kali lebih besar untuk terkena KEK dibandingkan dengan tingkat asupan energi cukup (Tabel 5). Seperti yang telah diketahui sebelumnya, prevalensi KEK di Kecamatan Sedayu mengalami peningkatan dan prevalensinya lebih tinggi dibandingkan prevalensi di DIY dan Bantul. Hal ini dapat disebabkan oleh tingkat asupan energi pada kelompok risiko KEK lebih banyak yang rendah dibandingkan dengan kelompok tidak berisiko KEK. Secara statistik juga menunjukkan hasil bahwa terdapat perbedaan yang signifikan antara asupan energi pada kelompok risiko KEK dengan kelompok tidak berisiko KEK. Median asupan energi pada kelompok risiko KEK cenderung lebih rendah 507,2 Kalori dibandingkan kelompok tidak berisiko KEK. Jika dilihat dari proporsi asupan energi berdasarkan kuartil menunjukkan bahwa proporsi risiko KEK cenderung akan semakin meningkat jika asupan energi ibu hamil $\leq 1.926,5$ Kalori (Gambar 1). Dengan demikian, terjadinya risiko KEK pada ibu hamil di Kecamatan Sedayu dapat dipastikan secara langsung disebabkan oleh tingkat asupan energi yang rendah. Asupan energi yang rendah pada ibu hamil di Kecamatan Sedayu dapat disebabkan ibu hamil tersebut banyak berasal dari keluarga yang rawan pangan yaitu sebesar $39,4 \%$ dan keluarga rawan pangan ini cenderung memiliki tingkat pengeluaran dan pendapatan per kapita yang rendah dan berasal dari keluarga yang kurang sejahtera.

\section{Hubungan antara tingkat asupan protein dengan KEK pada ibu hamil}

Pada penelitian ini didapatkan hasil bahwa tidak ada hubungan yang signifikan antara tingkat asupan protein dengan risiko KEK pada ibu hamil $(p>0,05)$ (Tabel 4). Beberapa penelitian lain di Semarang tahun 2004 menunjukkan hasil yang sama, yaitu tidak terdapat hubungan yang signifikan antara tingkat asupan protein dengan kejadian KEK ibu hamil $(11,20)$. Hal tersebut dimungkinkan dipengaruhi oleh faktor lain seperti tingkat asupan energi. Walaupun asupan protein ibu kurang, jika asupan energinya mencukupi kebutuhan, maka risiko KEK tidak dapat terjadi. Selain itu KEK digunakan untuk menggambarkan keadaan kurang energi yang lebih menonjol daripada kurang protein (21). Hal ini sudah dijelaskan sebelumnya pada penelitian ini yaitu asupan energi sangat berhubungan erat dengan risiko KEK pada ibu hamil. Walaupun asupan protein tidak berhubungan dengan risiko KEK pada ibu hamil, namun asupan protein tetap harus dipenuhi oleh ibu hamil, mengingat adanya peningkatan kebutuhan protein untuk kesehatan ibu dan janin, serta protein tersebut mempunyai fungsi utama yang tidak dapat digantikan dengan zat gizi lain yaitu sebagai zat pembangun dan pemelihara sel-sel/jaringan tubuh.

Meskipun secara statistik tidak berhubungan, jika dilihat dari proporsi ibu hamil dengan asupan protein rendah lebih banyak mengalami risiko KEK. Hasil penelitian ini juga menunjukkan bahwa proporsi risiko KEK akan semakin menurun jika asupan protein ibu hamil $>60,7$ gram atau dengan kata lain, semakin tinggi asupan protein ibu hamil, maka proporsi risiko KEK cenderung menurun dan proporsi risiko tidak KEK cenderung meningkat (Gambar 2). Selain itu, perbedaan asupan protein ibu hamil terlihat antara kelompok risiko KEK dengan kelompok tidak berisiko KEK, yaitu median asupan protein pada kelompok risiko KEK cenderung lebih rendah 18,8 gram dibandingkan kelompok tidak berisiko KEK. Penelitian lain juga menunjukkan hasil yang sama yaitu proporsi ibu hamil yang memiliki cukup protein lebih sedikit yang menderita KEK dibanding dengan ibu hamil yang kurang asupan proteinnya. Hal ini berarti jika seseorang terpapar 
asupan protein rendah, maka ia akan memiliki peluang lebih besar untuk menderita KEK (5). Dengan demikian, asupan protein rendah pada ibu hamil akan berpeluang untuk terkena KEK dan hal ini juga sudah dibuktikan pada analisis bivariat yang menunjukkan bahwa ibu dengan tingkat asupan protein rendah memiliki risiko 2,1 kali lebih besar untuk terkena KEK dibandingkan ibu dengan tingkat asupan protein cukup (Tabel 4). Hal ini sudah dibuktikan oleh penelitian lain yang menunjukkan bahwa pemberian makanan tambahan sumber protein terbukti dapat meningkatkan kecukupan gizi pada ibu hamil (22).

\section{Hubungan antara ketersediaan pangan dengan KEK pada ibu hamil}

Ketersediaan pangan dalam keluarga mempengaruhi banyaknya asupan makan anggota keluarga. Semakin baik ketersediaan pangan suatu keluarga memungkinkan terpenuhinya seluruh kebutuhan zat gizi. Jika ketersediaan pangan di rumah tangga menurun, otomatis konsumsi makan dan konsumsi zat gizi per anggota keluarga berkurang sehingga menyebabkan masalah gizi, diantaranya kejadian KEK (11).

Berdasarkan proporsi ibu hamil dengan keluarga rawan pangan lebih banyak mengalami KEK. Selain itu, hasil uji statistik menunjukkan bahwa ada hubungan yang signifikan antara ketersediaan pangan dengan risiko KEK pada ibu hamil (Tabel 4). Hasil yang sama ditunjukkan pada penelitian lain menyatakan bahwa ada hubungan yang signifikan antara ketersediaan pangan dengan kejadian KEK (23). Jika dilihat dari risikonya, ibu dengan keluarga rawan pangan memiliki risiko 2,6 kali lebih besar untuk terkena KEK dibandingkan dengan ketersediaan pangan terjamin (Tabel 5). Ketersediaan pangan dapat memicu terjadinya risiko KEK pada ibu hamil karena dengan terbatasnya ketersediaan pangan, maka ibu hamil akan mengalami kekurangan zat gizi terutama energi sehingga jika asupan energi rendah maka risiko KEK dapat terjadi. Hal ini didukung juga dengan hasil penelitian lain yang dilakukan di NTT menyebutkan bahwa terbatasnya ketersediaan makanan dan rendahnya kemampuan untuk menyediakan makanan sumber zat gizi akan menyebabkan ibu hamil mengalami defisit energi sampai dengan $40 \%$ atau lebih (24).

\section{KESIMPULAN DAN SARAN}

Terdapat hubungan yang signifikan antara tingkat asupan energi dan ketersediaan pangan dengan risiko KEK pada Ibu hamil di Kecamatan Sedayu. Selain itu, tingkat asupan energi memiliki hubungan yang paling kuat dengan risiko KEK pada ibu hamil dibandingkan dengan ketersediaan pangan. Untuk mengatasi hal tersebut, perlu adanya peningkatan program pemberian makanan tambahan (PMT) pemulihan untuk ibu hamil dan tidak hanya memperhatikan kuantitas tetapi juga kualitasnya, serta dapat dilakukan pemantauan/monitoring pemberian PMT agar tepat sasaran. Tidak terdapat hubungan yang signifikan antara tingkat asupan protein dengan risiko KEK pada ibu hamil di Kecamatan Sedayu. Sebaiknya, dilakukan penelitian lebih lanjut pada cakupan yang lebih luas dimana tidak hanya di Kecamatan Sedayu saja tapi juga dapat dilakukan di beberapa kecamatan yang ada di Kabupaten Bantul sehingga jumlah sampel menjadi lebih besar.

\section{RUJUKAN}

1. Rao KM, Balakrishna N, Arlappa N, Laxmaiah A, Brahmam GN V. Diet and nutritional status of women in India. J Hum Ecol 2010;29(3):16570.

2. Departemen Kesehatan RI. Program gizi makro. Jakarta: Direktorat Gizi Masyarakat Depkes; 2002.

3. Kementerian Kesehatan RI. Laporan riset kesehatan dasar. Jakarta: Badan Penelitian dan Pengembangan Kesehatan Kementerian Republik Indonesia; 2013.

4. Dinkes. Profil kesehatan Provinsi D.I.Yogyakarta tahun 2011. DIY Yogyakarta; 2012.

5. Ausa ES, Jafar N, Indriasari R. Hubungan pola makan dan status sosial ekonomi dengan kejadian KEK pada ibu hamil di Kabupaten Gowa tahun 2013. Universitas Hasanuddin; 2013. 
6. Bendich A. Handbook of nutrition and pregnancy. New Jersey: Humana Press; 2008.

7. Almatsier S. Prinsip dasar ilmu gizi. Jakarta: Gramedia Pustaka Utama; 2003.

8. Waryono. Gizi reproduksi. Yogyakarta: Pustaka Rihana; 2010.

9. Gibson. Principle of nutrition assessment. New York: Oxford University Press; 2005.

10. Achadi E. Gizi kesehatan masyarakat. Depok: Departemen Gizi dan Kesehatan Masyarakat; 2007.

11. Priswanti. Hubungan ketersediaan pangan keluarga dan tingkat asupan energi protein, fe, asam folat, vitamin B12 dengan kejadian kurang energi kronis (KEK) dan anemia pada ibu hamil. Universitas Diponegoro; 2004.

12. Badan Ketahanan Pangan dan Penyuluhan. Asupan dan kewaspadaan pangan [Internet]. 2013 [cited 2013 Sep 30]. Available from: http:// bkpp.jogjaprov.go.id/content/page/245/BidangAsupan-Dan-Kewaspadaan-Pangan

13. Badan Perencanaan Pembangunan Daerah Bantul. Rencana pembangunan jangka menengah daerah tahun 2011-2015. Bantul: Bappeda Bantul; 2011.

14. Dinas Kesehatan Kabupaten Bantul. Profil gizi Kabupaten Bantul. Bantul: Dinas Kesehatan Kabupaten Bantul; 2012.

15. Aritonang, Evawany. Kebutuhan gizi ibu hamil. Bogor: IPB Press; 2010.

16. Krisnawati N. Hubungan tingkat konsumsi pada ibu hamil dengan kekurangan energi kronis ( KEK ) di Puskesmas Wonoayu Kabupaten Sidoarjo. Surabaya: Universitas Airlangga; 2010.

17. Hermawan. Faktor-faktor yang berpengaruh terhadap risiko kurang energi kronis (KEK) pada ibu hamil di Kecamatan Cimalaka Kabupaten Sumedang. Institut Pertanian Bogor; 2006.

18. Irawan AMA, Thaha AR, Virani D. Hubungan asupan energi dan protein dengan status IMT dan LILA ibu prakonsepsional di Kecamatan Ujung Tanah dan Biringkanaya Kota Makassar. Universitas Hasanuddin; 2013.

19. Nahar S, Mascie-Taylor CGN, Begum HA. Impact of targeted food supplementation on pregnancy weight gain and birth weight in rural Bangladesh: an assessment of the Bangladesh Integrated Nutrition Program (BINP). Journal Public Health Nutrition. 2009 Aug [cited 2013 Oct 4];12(8):1205-12. Available from: http:// www.ncbi.nlm.nih.gov/pubmed/18838027

20. Ginting HM. Hubungan Tingkat asupan energi dan protein dengan status gizi ibu hamil di Kelurahan Purwoyoso Kecamatan Ngaliyan. Universitas Muhammadiyah Semarang; 2010.

21. Baliwati YF. Khoisan A, Dwiriani C. Pangan dan gizi. Jakarta: Penebar Swadaya; 2004.

22. Prihananto V, Sulaeman A, Riyadi H. Pengaruh pemberian makanan tambahan terhadap konsumsi energi dan protein ibu hamil. JGIZIPANGAN . 2007;2(1):16-21.

23. Simarmata M. Hubungan pola asupan, ketersediaan pangan, pengetahuan gizi dan status kesehatan dengan kejadian kek pada ibu hamil di Kabupaten Simulungun. Universitas Sumatera Utara; 2008.

24. Hadi H, Manongga S, Arjuna T, Irwanti W, Lada CO. Analisis tentang perilaku dan praktek konsumsi makanan/diet pada anak dibawah 5 tahun, anak sekolah, ibu hamil dan ibu menyusui di Kabupaten Timor Tengah Selatan, Provinsi Nusa Tenggara Timur, Indonesia. Yogyakarta; 2013 p. 58-59. 